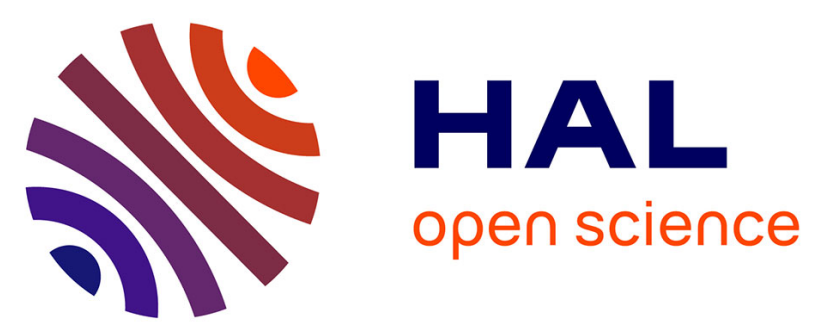

\title{
STUDYING WITH A FULL-FIELD MEASUREMENT TECHNIQUE THE LOCAL RESPONSE OF ASPHALT SPECIMENS SUBJECTED TO FREEZE- THAW CYCLES
}

M C Teguedi, B Blaysat, Evelyne Toussaint, Sylvia Moreira, S Liandrat, M Grédiac

\section{To cite this version:}

M C Teguedi, B Blaysat, Evelyne Toussaint, Sylvia Moreira, S Liandrat, et al.. STUDYING WITH A FULL-FIELD MEASUREMENT TECHNIQUE THE LOCAL RESPONSE OF ASPHALT SPECIMENS SUBJECTED TO FREEZE- THAW CYCLES. SEM (Society for Experimental Mechanics) Annual Conference, Jun 2017, Indianapolis, United States. hal-01657726

\author{
HAL Id: hal-01657726 \\ https://hal.uca.fr/hal-01657726
}

Submitted on 7 Dec 2017

HAL is a multi-disciplinary open access archive for the deposit and dissemination of scientific research documents, whether they are published or not. The documents may come from teaching and research institutions in France or abroad, or from public or private research centers.
L'archive ouverte pluridisciplinaire $\mathbf{H A L}$, est destinée au dépôt et à la diffusion de documents scientifiques de niveau recherche, publiés ou non, émanant des établissements d'enseignement et de recherche français ou étrangers, des laboratoires publics ou privés. 


\title{
STUDYING WITH A FULL-FIELD MEASUREMENT TECHNIQUE THE LOCAL RESPONSE OF ASPHALT SPECIMENS SUBJECTED TO FREEZE- THAW CYCLES
}

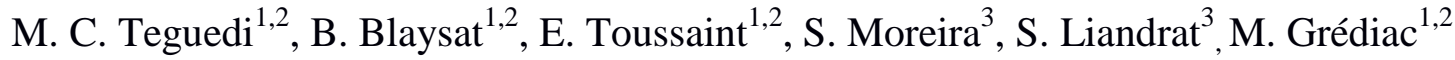 \\ ${ }^{1}$ Université Clermont Auvergne, Institut Pascal, BP 10448, 63000, Clermont-Ferrand, France \\ ${ }^{2}$ CNRS, UMR 6602, Institut Pascal, 63171, Aubière, France \\ ${ }^{3}$ Département Laboratoire de Clermont-Ferrand (CEREMA, DterCE) \\ E-mail: michel.grediac@ univ-bpclermont.fr
}

Keywords: Recycled Asphalt, Thermal contraction/expansion, Strain field, Freeze-thaw, Grid method, Digital image correlation

\section{EXTENDED ABSTRACT}

In cold regions, pavements suffer from the thermal cracking caused by the contraction and expansion of asphalt under temperature changes. The thermal behavior of asphalt at the macroscopic scale has been widely studied using testing devices such as the Asphalt Thermal Cracking Analyzer (ATCA) [1] and the Asphalt Concrete Cracking Device (ACCD) [2]. However, since low temperature damages are initiated in the internal structure of asphalt mixtures, understanding the thermal response of asphalt components (bitumen and aggregates) is of great practical importance to have a better understanding of the overall thermal response of pavements. The major problem is however to measure the local thermal response of these materials.

Full-field measurement techniques, which have now widely spread in experimental mechanics, are useful to have a better understanding of the asphalt behavior under thermal loadings. In recent years, these methods have become major tools to inspect and characterize the mechanical response of such materials. The main full-field measurement methods that are used by the pavement community are the digital image correlation (DIC) [3-5] and more recently the grid method (GM) [6,7]. This last technique was used here because it exhibits a good compromise between spatial resolution and measurement resolution [8], which is crucial here, the material under investigation being highly heterogeneous. Till now, the application of such measurement techniques for the characterization of asphalt was limited to their mechanical response, and few emphasis has been placed on the investigation of their thermal response.

In this study, four Hot Mixtures Asphalt (HMA) specimens with 0\%, 20\%, 40\% and 100\% of RAP (Recycled Asphalt

Pavement) content were considered. These materials were used in a previous study, which was devoted to the characterization of the effect of RAP on the local mechanical behavior of recycled asphalt pavements [6]. These RAP materials are composed of granite, basalt and gneiss. The virgin materials are constituted from limestone aggregates and a virgin bituminous binder. Freeze-thaw tests were carried out on these materials. They were performed in a climate chamber at a temperature range of $\left[-10^{\circ} \mathrm{C} 20^{\circ} \mathrm{C}\right]$. At the global scale, the specimens exhibited an anisotropic behavior along both the vertical and horizontal directions. The comparison of the global strain-temperature curves showed that the inclusion of $100 \%$

RAP resulted in an increase of the Coefficient of Thermal Contraction (CTC) of the specimen. Typical examples of the displacement fields obtained for the $100 \%$ RAP specimen at $\mathrm{T}=-10^{\circ} \mathrm{C}$ are shown in

Figure 1. These displacements correspond to a difference in temperature equal to $\Delta \mathrm{T}=-30^{\circ} \mathrm{C}$. The displacement fields presented in

Figure $1 \mathrm{a}$ and $1 \mathrm{~b}$ clearly illustrate the global contraction of the specimen along the vertical and horizontal direction. From these results, it is visible that the specimen shrinks toward its center. Another representation of the displacement fields is proposed in 
Figure 1c. In this figure, the displacement fields are used to deform a regular mesh to help the reader figure out the deformation of the specimen. The pitch of the mesh is equal to 10 pixels and the displacement multiplied by 350 to give a clearer idea on the deformation of the specimen. This presentation is expressed in the deformed configuration. The overall contraction of the specimen towards its center is clearly visible. This contraction is mainly sustained by the mastic. Strain maps which are deduced from these displacement maps then enable us to characterize, among others, the in-situ coefficient of thermal expansion of the binder.

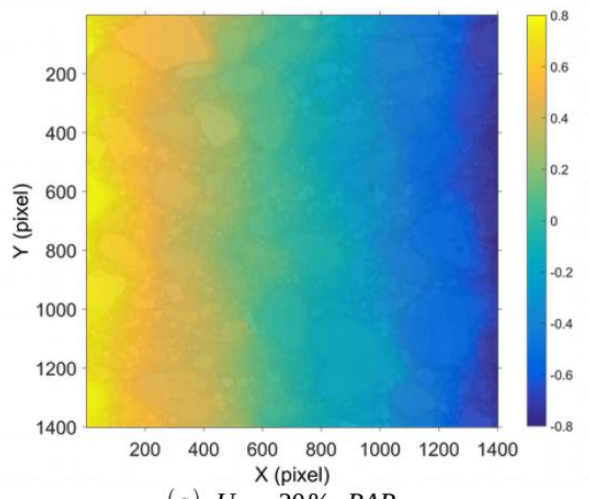

(a) $U_{x x}, 20 \% R A P$

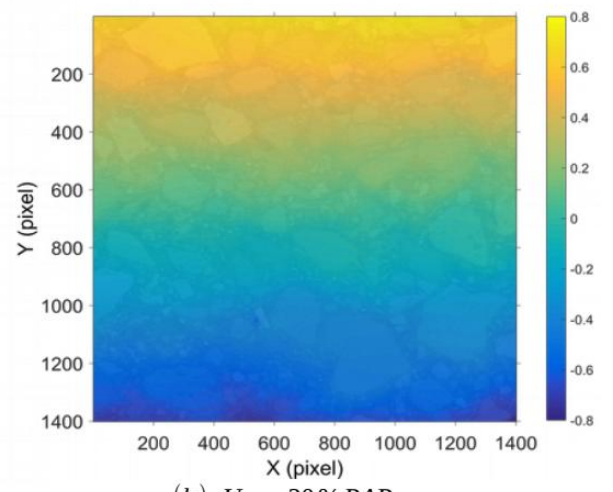

(b) $U_{y y}, 20 \% R A P$

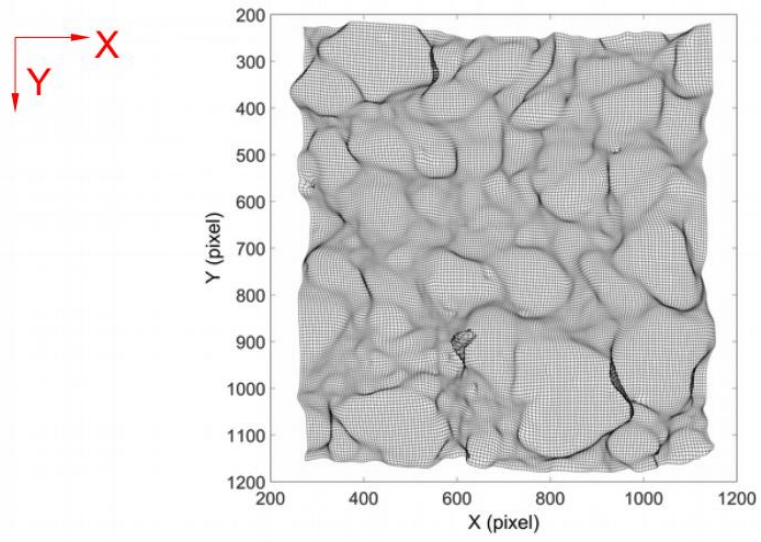

(c) Magnified deformed mesh

Figure 1 Typical displacement fields for the $100 \%$ RAP specimen at $\mathrm{T}=-10^{\circ} \mathrm{C}$ (in pixels, 1 pixel $=40 \mu \mathrm{m}$ )

Finally, it can be concluded that the paper brings new information on the thermal contraction/expansion of asphalt materials at length scales ranging from binder to the mixture scales. In particular, it was possible to quantify the influence of the RAP on this response.

\section{REFERENCES}

[1] Stimilli, A., Canestrari, F., Teymourpour, P., Bahia, H. U.«Low-temperature mechanics of hot recycled mixtures through Asphalt Thermal Cracking Analyzer (ATCA)». Construction and Building Materials, 2015. Vol. 84, p. 54-65.

[2] Akentuna, M., Kim, S. S., Nazzal, M., Abbas, A. R., Arefin, M. S. «Study of the thermal stress development of asphalt mixtures using the Asphalt Concrete Cracking Device (ACCD) ». Construction and Building Materials, 2016. Vol. 114, p. 416- 422.

[3] Romeo E. «Two-dimensional digital image correlation for asphalt mixture characterisation: interest and limitations ». Road Materials and Pavement Design, 2013. Vol. 14, n 4, p. 747- 763.

[4] Ktari R., Millien A., Fouchal F., Pop I.O., Petit C. «Pavement interface damage behavior in tension monotonic loading ». Construction and Building Materials. 2016. Vol. 106, p. 430- 442.

[5] Hill B., Buttlar W. G. «Evaluation of polymer modification in asphalt mixtures through digital image correlation and performance space diagrams ». Construction and Building Materials, 2016. Vol. 122, p. 667- 673.

[6] Teguedi M. C., Blaysat B., Toussaint E., Moreira S., Liandrat S., Grédiac M. «Applying a full-field measurement technique for studying the local deformation in reclaimed asphalt pavements ». Construction and Building Materials, 2016. Vol. 121, p. 547- 558. 
[7] Teguedi M. C., Toussaint E., Blaysat B., Moreira S., Liandrat S., Grédiac M. «Studying the Influence of the Reclaimed Asphalt Pavement (RAP) on Local Deformation Properties of Asphalt Mixtures ». In: Zhu Y, Zehnder AT (éd.). Experimental and Applied Mechanics, 2017. p. 159-163.

[8] Grédiac, M., Blaysat, B., Sur, F., «A critical comparison of some metrological parameters characterizing local digital image correlation and grid method». In revision 